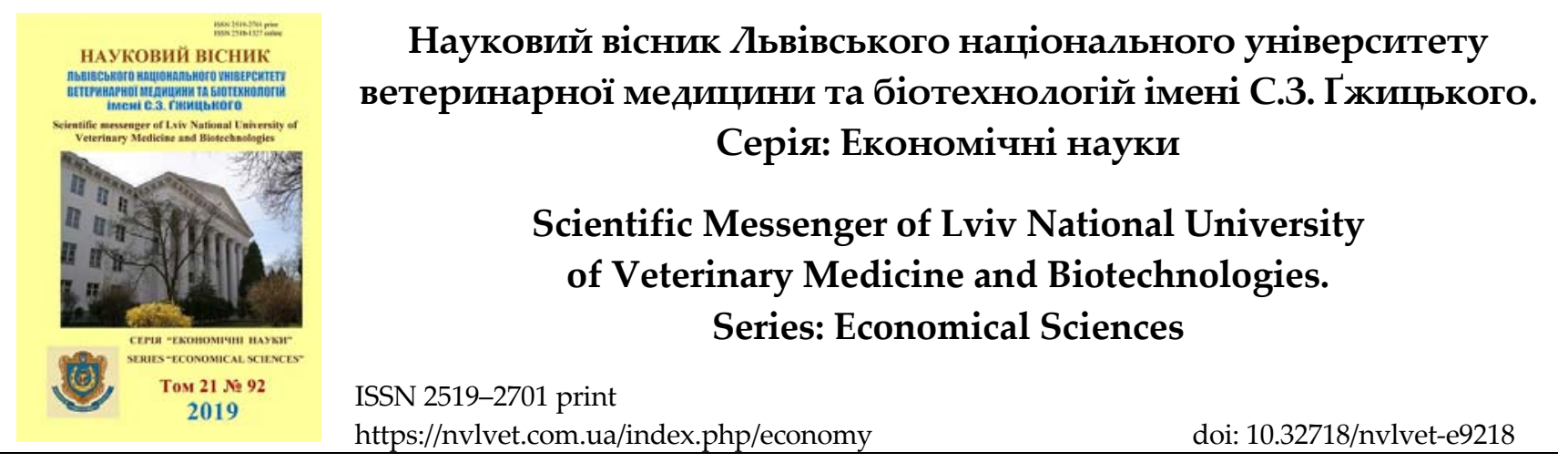

UDC 332/3.334

\title{
Success Factors of Land Reform and Sustainable Rural Development: History Background and Tendencies
}

\author{
A. Domanskyj \\ Stepan Gzhytskyi National University of Veterinary Medicine and Biotechnologies Lviv, Ukraine
}

Article info

Received 05.02.2019

Received in revised form 06.03 .2019

Accepted 07.03.2019

Stepan Gzhytskyi National University of Veterinary Medicine and Biotechnologies Lviv,

Pekarska Str., 50, Lviv,

79010, Ukraine.

Tel.: +38-(032) 239-26-26

E-mail:andrij.domanskiy@gmail.com
Domanskyj, A. (2019). Success Factors of Land Reform and Sustainable Rural Development: History Background and Tendencies. Scientific Messenger of Lviv National University of Veterinary Medicine and Biotechnologies. Series: Economical Sciences, 21(92), 110-114. doi: $10.32718 /$ nvlvet-e9218

Success factors of the of land reforms and sustainable development of the rural areas. Ownership and use of land resources has a dynamic and increasing tendency towards the concentration of land by certain state and public institutions as well as individuals in the historical aspect. It leads to the enrichment of the small monopolists and the poverty of the village. Usually, when a critical limit of conflict will be reached, it should be resolved by state reforms. From the second half of the 19th century, on the territory of today's Ukraine there were three significant land reforms. First two are the reforms in 1848 in Austrian-Hungary, and Stolypin reform of 1906-1907. Their purpose and solutions can be directly related to the land reform that has started in the beginning of 1991 in Ukraine. Until now, this reform has not yet been fully implemented. It causes a number of progressive prods, connected primarily with the land market. The moratorium on the sale of agricultural land does stands in the way of land mortgages, land capital, investment attractiveness, issues related to land protection, soil fertility conservation, land use optimization, excessive use, land reclamation, and the development of small and medium-sized agricultural producers. Small and large villages have been disappearing, the problems of preserving forests, reservoirs, and biological diversity has been worsening. Certain risks can be seen in the newly amalgamated territorial communities as there is a high dependence between the number of village councils and villages. There are different models of land reforms applied in the world. European models of land reform, particularly Polish and French models are the most suitable in the light of current situation in Ukraine. The model of the harmonious development of rural areas, covering about $90 \%$ of the entireterritory of the country, should be based on the paradigm of sustainable development. In Europe, three major models of rural development have emerged: sectoral based on the development of agriculture; redistribution, which involves the reduction of discrepancies between the more underdeveloped rural areas and advance industries and the territorial (cluster) model that implies the development of the rural territories is carried out on the basis of the corresponding interdependencies within the local economy. There five models of rural development in Ukraine at the current stage: sectoral (intersectoral); redistributive; cluster; model, focused on the village, that entails priority given to meet the needs of the specific territory and local tradition preservation; and finally, the mixed, based on several components of the different models, mainly sectoral and cluster. Education, professional enhancement, spirituality and Christian ethics, citizens' activism and civic society development also belongs to the crucial factors for the sustainable development of rural areas.

Key words: rural areas, land market, land reform, amalgamated communities, non-governmental organizations, spirituality, trust.

\section{Чинники успіху земельних реформ i розвитку сільських теритоій: історичний досвід та перпспективи}

\author{
А.Я. Доманський
}

Львівський національний університет ветеринарної медицини та біотехнологій імені С.3. Гжиџького, 


\section{м. Львів, Украӥна}

В історичному аспекті володіння і користування землею має динамічну тенденцію до концентрації земель певними державними і суспільними інституціями та приватними особами, що приводить до монополізму і збагачення невеликого числа монополістів і зубожіння багато численного селянства. Критична межа конфліктів вирішується державними реформами. Від другої половини 19-го століття на території України відбулися три значні земельні реформи: 1848 року в Австро-Угоричині,Столипінська реформа 1906-1907 років в Російській імперії. Обидві еформи за своєю метою і способами їх вирішення мають безпосередній стосунок до розпочатої на початку 1991 року аграрної (земельної) реформив Україні. До иих пір реформа не завериена. Це викликає ряд прогресуючих проблем, пов язаних насамперед з ринком землі. Мораторій на продаж земель сільськогосподарського призначення не дозволяє вирішити ряд питань пов 'язаних з з охороною земель, збереженням їх родючості оптимізачією землекористування тощо.Певні ризики криються в об'єднанні територіальних громад, оскільки є висока залежність між кількісю сільрад і сіл. Існують різні моделі земельних реформ. В Україні найприваблішими є реформи європейські, насамперед польська $і$ франиузька. В Свропі сформувалися три основні моделі розвитку сільських територій:галузева, перерозподільча ,та теріторіальна.(кластерна). В Україні крім них є ще селоцентристська(селозберігаюча) і мішана. Надзвичайно важливими є фактори освіти,професіональних знань, духовності,питання віри і довіри, громадянської активності, розвиток громадських організацій.

Ключові слова: сільські території, ринок землі, земельні реформи, громадські організації, духовність, довіра.

\section{Вступ}

Уже більше чверті століття від часу початку земельної реформи, а вона все ще є незавершеною. Із плином часу цей, один із найскладніших вузлів соціально-економічного життя українського селянства не тільки не розв'язується, а, навпаки, обростає новими пучками проблем, пов'язаними із недостатньо продуманими, логічно необгрунтованими законами і законодавчими актами та постановами, Безкінечне продовження мораторію на ринок земель сільськогосподарського призначення заганяє проблему в тунель, з якового виходу може не бути, бо не буде тих ради кого проводиться реформа-дієздатних селян, сільських господарів,виробників сільськогосподарської продукції. Децентралізація, створення сільських територіальних громад несе нові виклики і загрози життєдіяльності сільських територій. Все це вимагає детального аналізу проблем, вивчення вітчизняного та закордонного досвіду, вироблення обгрунтованих пропозицій 3 питань ринку землі, іiі використання, ролі в цих процесах селян, громадських організацій.

\section{Матеріал і методика досліджень}

В процесі дослідження використовувалися методика наукового пошуку: монографічний, узагальнюючий, аналізу та синтезу, індукції та дедукції, аналіз причинно-наслідкових зв'язків економічних явич i процесів в аграрному секторі економіки.

\section{Результати та їх обговорення}

Земельні та людські ресурси є основою життєдіяльності сільських територій. Вони забезпечують виробництво продукту - продовольчих товарів, є одним 3 найважливіших факторів створення рівня якості життя населення. Питанню використання і обороту земель сільськогосподарського призначення i ролі людини в цих процесах присвячували свої роботи П.Т. Саблук, В.В. Юрчишин, А. Гор, Ю.Е. Губені, Ю.О. Лупенко, О.В. Ходаківська, О.М. Шпичак, О.М. Нечипоренко, А.С. Попов, М.П. Мартинюк, I.В. Юрченко, В.К. Збарський, П.М. Музика, М.I. Грицаєнко, М.Ф. Кропивко, М.М. Федоров, Б.О. Сидорук, Я.М. Гадзало, Ю.Я. Лузан, В.Я. Ме-
сель-Веселяк і багато інших вчених (Hadzalo \& Luzan, 2017; Martyniuk, 2017; Lupenko, 2017; Hrytsaienko, 2018; Mahas et al., 2018).

Володіння земельними ресурсами має постійну концепцію(парадигму) до концентрації і накопичення земель державними і суспільними інституціями та приватними особами чи корпоративними групами. Завдяки ефекту великого землеволодіння (зменшення трансакційних витрат на одиницю площі землі), спеціалізації, монополізації ця нечисленна група збагачується і прибирає до своїх рук важелі не тільки економічної, але й політико-правової та регулятивної влади. В той же час вся основна маса селян бідніє, зубожіє і перестає бути господарем землі ї споживачем їі благ, рушієм суспільного прогресу. Наступає критична маса конфлікту інтересів, який може бути розв'язаний лише шляхом корінних реформ. В іншому випадку це загрожує соціальним вибухом чи повстанням. В історичному аспекті на європейському континенті за останні три століття такі реформи відбувалися через кожні 30-70 років, а в середньому через півстоліття. Це залежить в першу чергу від суспільнополітичного,економічного устрою держави , досконалості попередніх реформ і ряду інших обставин, що зачіпають інтереси населення.

Від другої половини 19-го століття на території, що охоплює сьогоднішню Україну відбулися три значимі земельні реформи, які за своєю метою і проведенням мають стосунок до проблем сьогодення. Перша - це реформа 1848 року в Австро-Угорщині в складі якої перебували західно-українські землі (Галичини), які за площею займали 8,1\% всієї імперії. Друга - це Столипінсьа реформа 1906-1907 років в Російській імперії. Третя - це земельна (аграрна) реформа, розпочата в 1991 році в уже незалежній Україні, яка i досі не завершена. За реформою 1848 року відбулось подрібнення (парцеляція)великих поміщицьких землеволодінь і передача іï за викуп селянам. В 1902році в Галичині нараховувалось 653692 господарства. В структурі цих господарств бідняцькі (карликові) господарства, що володіли землею площею до 2 га - 43\%, бідняцькі дрібні (2-5 га) $37 \%$, середняцькі - (5-10 га) - 14,5\%, багацькі (10100 га) - 4,8\%, поміщицькі (понад 100 га) - 0,6\% (Zlupko, 1999). Негативною стороною реформи було те, що багато селян (безземельні або карликові), не 
маючи коштів, навіть при довгострокових кредитах, але при високих кредитних ставках (12\%) відмовлялися від землі, або повертали землю Не маючи засобів виробництва і не маючи фахових сільськогосподарських знань,новоявлені власники землі не мали прибутку і не могли в достатній мірі стати ефективним товаровиробником. Слід відзначити, що в другій половині 19-го століття в Західній Свропі почали діяти громадські організації, в тому сільськогосподарського профілю, фінансові кредитні спілки, кооперативи, організації завданням яких було навчання агрономічної культури і виховання молоді, прищеплення їм християнських цінностей, патріотизму i професійних знань. Саме таку мету поставила перед собою національна українська громадська організація “Товариство” Сільський господар”, засноване 23 березня 1899 року. Завдяки йому продукція українських селян Галичини стала основною не тільки на внутрішньому ринку, але і успішно конкурувала на зовнішніх ринках Західної Свропи.

Успішність реформ залежить від того, наскільки в iii підготовці і реалізації приймають участь ті, ради кого ця реформа проводиться. В.М. Магас, О.Я. Гримак, В.А. Чемерис (Mahas et al., 2018) наводять твердження лауреата Нобелівської премії Фрідріха фон Гаєка про те, що жоден науковець чи чиновник, жоден колегіальний орган із їх числа в принципі не здатні оволодіти потрібним обсягом знань, які б дозволили задавати оптимальні шляхи розвитку, вирішення локальних і глобальних економічних проблем. I тому, як зазначають автори, це можливе лише за умови вивільнення простору для реалізації знань мільйонів звичайних жителів сіл, підприємців та багато інших громадян. Підтвердженням цієї істини є Солипінська реформа 1906-1907 років і вважається доволі успішною. За п'ять років до іiі проведення в губерніях і повітах було створено більше 600 комітетів із виявлення думки селян щодо володіння і користування землею. Більшість місцевих комітетів висловились за перехід від громадського до приватного землеволодіння, але без будь-яких примусових заходів. Кожний член громади діставав право виділити свою частку в особисте володіння незалежно від згоди інших членів громади. П. Столипін наголошував, що “доки селянин бідний, не володіє особистою земельною власністю, поки він знаходиться в лещатах громади він залишається рабом і ніякий писаний закон не дасть йому блага громадянської свободи... не можна любити чуже на рівні із своїм і не можна плекати землю, що знаходиться в тимчасовому користуванні так, як і свою землю. Штучна, в цьому відношенні, кастрація нашого селянства, зниження в ньому почуття власності веде до багатьох дурниць, головне - до бідності. А бідність, по мені, гірше із рабств. Смішно говорити цим людям про волю і вольність”. Столипінська реформа грунтувалася на поєднанні двох шляхів: американського (фермерського) і пруського, при якому зберігалось ефективне, високопродуктивне поміщицьке землеволодіння. Столипінський шлях передбачав існування чотирьох укладів: державного, великого приватного,громадського і сімейнотрудового або малого приватного землеволодіння.
Головною суттю реформи було не тільки руйнація общини, a, головне - створення стану селянземлевласників, міцних господарів землі, при цьому робити це еволюційним шляхом. Цей шлях передбачав поступове переростання селянських господарств у вищий тип - фермерський, зорієнтований на ринок. Столипінська реформа супроводжувалась розвитком селянської кооперації (Verhunov, 2008) Світова війна,самодержавство, більшовицький переворот поставили хрест на особі Столипіна і його реформі.

Різниця між Столипінською і Українською реформою (на жаль, вона не стала персоніфікованою) є в тому, що перша готувалась 5 років, а була проведена за два роки. Реформа в Україні уже продовжується більше чверть століття, що $є$, мабуть, світовим рекордом за три-чотири століття. Реформа проводилась заради історичної справедливості: повернути власникам насильно забрану в них землю і зробити 3 них повноправних господарів. Як і в Столипінській реформі, реформа в Україні передбачає багатоукладність типів сільгоспвиробників, а потрібно було законодавчо закріпити пріоритетність малих господарських форм, малого і середнього бізнесу. Нині із 6,9 млн власників земельних паїв $23 \%$ мають вік понад 70 років, а 1,4 млн (20\%) уже померли. 10 найбільших агроутворень налічують у своєму землекористуванні 3 млн гектарів земель, одержуючи монопольну ренту і постійно нарощуючи свої надприбутки. Офіційний рівень безробіття в селах вищий, ніж в містах За останні 16 років сільське населення зменшилось на 2,9 млн осіб або на 18,1\%, на 60\% перевищує темпи скорочення населення міст Власники паїв у 2016 році одержали лише по 845,6 грн орендної плати за гектар, зданих в оренду земельних угідь. Структура посівних площ в середньому по Україні не відповідає ніяким науковим і господарським нормам господарювання i ефективного розвитку агропромислового комплексу. В цій структурі зернові і зернобобові займають 56,1\%, соняшник - 25,9, соя - 9,1, а кормові культури-лише мізерних 3,9\% при нормі не менше 25-30\%. Всі ці цифри (крім норми кормових культур) наведені 3 публікації М.П. Мартинюка, першого заступника міністра аграрної політики і продовольства України (Martyniuk, 2017). Автор зазначає, що “державним пріоритетом має бути безумовна підтримка невеликих сімейних ферм, від розвитку яких напряму залежить добробут сільських територій”. Потрібен новий механізм (методологія) адресної допомоги малим сільгоспвиробникам, за порушення якого повинна бути не тільки адміністративна, але й кримінальна відповідальність. Це ж стосується антимонопольного законодавства, штрафи за порушення якого повинні бути більшими за нанесені збитки. Як вказують Я.М. Гадзало і Ю. Лузан (Hadzalo \& Luzan, 2017) монополізм прогресує не тільки на ринку сільськогосподарської продукції, але i на ринку матеріально-технічних i фінансових ресурсів. Площа деградованих і малородючих земель перевищила 10 млн га. Відсутне збалансоване внесення органічних і мінеральних добрив, неконтрольовано використовуються засоби захисту росли, а це тільки знижує врожайність, але і загрожує здоров’ю людей в селах. Від 1990 року кількість сіль- 
ських населених пунктів зменшилась на 1,5\% або на 427сіл. Ю.О. Лупенко (Lupenko, 2017) вважає, що певні ризики криються в об'єднанні територіальних громад, оскільки, як свідчать результати досліджень, існує висока залежність між кількістю сільрад і сіл. На думку автора в Україні сформувалося п'ять основних моделей розвитку сільських територій:

1. Галузева (міжгалузева), що базується на ототожненні сільського розвитку із загальною модернізацією сільського господарства та агропромислового комплексу.

2. Перерозподільча, що пов'язує сільський розвиток із зменшенням відмінностей між найвідсталішими сільськими регіонами та іншими секторами економіки.

3. Територіальна (кластерна), що передбачає локальне формування економічно активних територіальних громад або територій на основі інтеграції усіх компонентів сільського розвитку, включаючи різні галузі.

4. Селоцентристська (селозберігаюча), що передбачає пріоритетне задоволення інтересів та збереження традицій сільського населення,характерних інституційних особливостей сільських територій.

5. Змішана, що грунтується на використанні окремих компонентів різних моделей. На нашу думку пріоритетними в цій моделі для гармонійною розвитку сільських територій мають бути компоненти територіальної (кластерної) та селоцентристської (селозберігаючої) моделей. Селоцентристська модель тоже 3 часом змінюється. Тоталітарні політичні режими були зацікавлені в ушільненні домогосподарств,житла. Тоді легше контролювати настрої селян, формувати потрібну громадську думку. Сьогодні у молоді, в середнього покоління є більша затребуваність в автономності, в розширенні присадибної площі,господарського двору, де була б можливість зберігати транспорт, сільгосптехніку,створювати розважальні відпочинкові майданчики для дітей тощо. Потрібні нові нормативи в забудову та облаштування сіл. В ідеалі землі сільськогосподарського призначення повинні прилягати до садиби сільського господаря як його власні, а не орендовані. Тому питання ринку землі, їі оренди ставиться в центр подальшого розвитку сільських територій і покращення якості життя на селі.

Серед багатьох світових моделей обороту і ринку земель для України представляють інтерес європейські моделі, зокрема польська, французька і інші як цілісні , так х окремі елементи. У статті 23 Конституції Польщі записано, що основою аграрного ладу польської держави є сімейне господарство. Покупцями та власниками земель сільськогосподарського призначення можуть бути тільки ті, які самі працюють на них. Згідно із Законом (2003 р.) розмір земельної ділянки, що купується, не може бути більшою 300га. А покупцем може бути тільки фізична особафермер, який керує фермерським господарством, де загальна площа сільгоспугідь становить не менше 1 гектара, але не більше 300 га; має сільськогосподарську освіту; проживає не менше п'яти років у місцевості, де знаходиться земельна ділянка; є одноосібним керівником фермерського господарства. Покупцем може бути юридична особа, якщо вона $є 3$ родини продавця ((нащадки,діти,дружина чи чоловік) Обіг земель регулює державна установа - Агенство сільськогосподарської нерухомості в Польщі, яка має право від імені держави купляти i продавати землю (Iurchenko, 2018). Згідно договору із продавцем агенство може виплачувати кошти продавцю поступово чи разово. У Франції регулятором ринку земель $є$ приватна неприбуткова організація - Агенство з управління земельними ресурсами та розвитку сільських територій (SAFER), діяльність якої контролюється державою в особі Міністерства сільського господарства та Міністерства фінансів. Між державним регулюванням та неолібералізмом є багато різних моделей земельних відносин і в рамках даної статті їх аналіз важко зробити. Проте, мусимо відзначити, що теоретичним підгрунтям неолібералізму є, як зазначають О.В. Ходаківська i Р. Левек (Khodakivska \& Levek, 2018), монетаризм, який передбачає максимізацію прибутків, залишаючи поза увагою ресурсні, екологічні і соціальні складові. А земельні ресурси обмежені і ліміт їх використання уже на межі закінчення. Збільшення антропогенного навантаження на обмежений природний ресурс викликало певне відчуження між людьми, між багатими і бідними, між владоможцями і населенням. Ідеолог і творець індійської незалежної держави Махатма Ганді говорив: “у світі достатньо ресурсів, щоб задовольнити потреби кожного, але зовсім недостатньо, щоб задовольнити жадібність хоча б однієї людини". Ганді говорив, орієнтуючись на спосіб і рівень життя тогочасного суспільства. Якщо ж брати рівень сьогоднішнього життя в розвинутих країнах і творити аналогічні умови в країнах ,що розвиваються і найбідніших то, згідно з німецькими дослідженнями планета потребує у шість разів більше ресурсів, ніж має фактично. Залежить від того ,який рівень життя у державі. Для обрання німецького рівня життя потрібне ресурсне забезпечення обсягом дві з половиною планети, на рівні забезпечення населення США - потрібний ресурс чотирьох таких планет як земля. Немає альтернативи тому, що єдиним способом зберегти достойне життя на землі і природнє середовище, довкілля $є$ сама людина, творець i споживач всіх земних благ. Лауреат Нобелівської премії, екс віце-президент США Альберт Гор у книзі “Земля у рівновазі, Екологія і людський дух" пише: "Я прийшов до висновку, що екологічна рівновага світу залежить не тільки від нашої здатності узгодити вовчі апетити цивілізації на ресурси із кригкою рівновагою земного довкілля; вона залежить лише від нашої здатності відновити рівновагу всередині себе між тим, ким ми є, і тим, що ми робимо”. Чим глибше я шукаю корені глобальної кризи довкілля, то тим більше переконуюся,щоце $є$ прояв внутрішньої кризи,тобто, за браком кращого слова - духовності". Саме духовності, національного патріотизму, професійних знань, віри і довіри нам бракує сьогодні. Як показав досвід діяльності громадської організації товариства “Сільський господар” в першій половині XX-го століття, а також розвинутих країн Європи i світу саме громадські професійні, релігійні, освітян- 
ські та інші організації є потужною формою і методом впливу на молодь і взагалі на людей та формування в них світоглядних позицій i моральності. Питання культури, традицій, звичаїв, мови визначають самобутність і внутрішне багатство людей, громад і всього суспільства.

\section{Висновки}

1. Земельна реформа в Україні повинна бути завершена в найкоротші строки, Але перед зняттям мораторію на ринок земель сільськогосподарського призначення повинна пройти повна інвентаризація земель, законодавчо прийняті всі запобіжні заходи для зловживань і розбазарювання земель, встановлені граничні норми володіння землею (не більше 200-300 га), створення всіх умов і конституційного закріплення пріоритетності малих господарських форм, фермерства.

2. Для обороту (обігу) земель сільськогосподарського призначення створити регулюючий орган(агенцію або під іншою назвою), наділивши іiі всіма необхідними функціями 3 найсуворішим державним і громадським контролем.

3. Для збереження природної родючості землі, розвитку сільських територійї необхідні певні зміни в законодавчі акти про оренду землі, які б обмежували надмірну концентрацію земель в одних руках, зобов'язували дотримуватись науково-обгрунтованих сівозмін і розвивати тваринництво.

4. Вибір моделей розвитку сільських територій повинен базуватись на кращих елементах територіальних та селозберігаючих моделях.

5. Забезпечення якості гармонійного життя в селах і сільських територіях в значній мірі залежить від духовності і моральності людей, їх професійних знань, від громадської активності і діяльності громадських організацій.

Перспективи подальших досліджень. Необхідні подальші дослідження в розробці рекомендацій по ринку землі, їх ефективного використання та покращення інфраструктури сільських територій.

\section{References}

Hadzalo, Ya.M., \& Luzan, Yu.Ia. (2017). Zemelna reforma: problemy i perspektyvy rozvytku ahrarnoi ekonomiky. Ekonomika APK, 1, 5-15.
http://nbuv.gov.ua/UJRN/E_apk_2017_1_3 (in Ukrainian).

Hrytsaienko, M.I. (2018). Sutnist sotsialnoho kapitalu ta yoho osoblyvosti v ahrarnii sferi. Ekonomika APK, 1, 60-65. http://eapk.org.ua/contents/2018/01/60 (in Ukrainian).

Iurchenko, I.V. (2018). Rehuliuvannia rynkovoho obihu zemel silskohospodarskoho pryznachennia: dosvid Polshchi. Ekonomika APK, 4, 88-94. http://eapk.org.ua/contents/2018/04/88 (in Ukrainian).

Khodakivska, O.V., \& Levek, R. (2018). Zemelni vidnosyny: poshuk balansu interesiv mizh derzhavnym rehuliuvanniam ta neoliberalizmom. Ekonomika APK, 6, 5-17. http://eapk.org.ua/ contents/2018/06/5 (in Ukrainian).

Levek, R., Khodakivska, O.V., \& Iurchenko, I.V. (2017). Modeli rehuliuvannia rynkovoho obihu zemel silskohospodarskoho pryznachennia $\mathrm{V}$ krainakh Yevropeiskoho Soiuzu. Ekonomika APK, 10, 5-12. http://eapk.org.ua/contents/2017/10/5 (in Ukrainian).

Lupenko, Yu.O. (2017). Stan ta perspektyvy staloho rozvytku silskykh terytorii. Ekonomika APK, 6, 7-11. http://nbuv.gov.ua/UJRN/E_apk_2017_6_4 (in Ukrainian).

Mahas, V.M., Hrymak, O.Ia., \& Chemerys, V.A. (2018). Metodolohichni reformuvannia ahrarnoi sfery. Naukovyi visnyk LNUVMBT imeni S.Z.Hzhytskoho, 20(91), 62-65. doi: 10.32718/nvlvet9113 (in Ukrainian).

Martyniuk, M.P. (2017). Rynok zemel silskohospodarskoho pryznachennia v Ukraini: stan ta perspektyvy. Ekono-mika APK, 3, 15-21. http://nbuv.gov.ua/UJRN/E_apk_2017_3_4

Nepochatenko, O.O., Kolotukha, S.M., Borovyk, P.M., \& Huzar, B.S. (2017). Zemelni vidnosyny ta finansovi aspekty yikh rozvytku. Ekonomika APK, 6, 42-52. http://www.eapk.org.ua/contents/2017/06/42 (in Ukrainian).

Verhunov, V.A. (2008). Stolypinska ahrarna reforma: peredumovy, zavdannia, zdiisnennia. Monohrafiia. Kyiv (in Ukrainian).

Zlupko, S. (1999). Na chatakh ridnoi zemli. Yevhen Khraplyvyi - uchenyi, orhanizator, patriot. Lviv: Vydvo LNU imeni Ivana Franka (in Ukrainian). 